\title{
Neurofibromatosis I and multiple sclerosis
}

\author{
Christina Bergqvist ${ }^{1,2}$, François Hemery ${ }^{3}$, Salah Ferkal ${ }^{2,4}$ and Pierre Wolkenstein ${ }^{1,2,4^{*}}$ (D)
}

\begin{abstract}
Neurofibromatosis 1 (NF1) is one of the most common autosomal dominant genetic disorders with a birth incidence as high as 1:2000. It is caused by mutations in the NF1 gene on chromosome 17 which encodes neurofibromin, a regulator of neuronal differentiation. While NF1 individuals are predisposed to develop benign and malignant nervous system tumors, various non-tumoral neurological conditions including multiple sclerosis (MS) have also been reported to occur more frequently in NF1. The number of epidemiologic studies on MS in NF1 individuals is very limited. The aim of this study was to determine the estimated population proportion of MS in NF1 patients followed in our Referral Centre for Neurofibromatosis using the Informatics for Integrated Biology and the Bedside (i2b2) platform to extract information from the hospital's electronic health records. We found a total 1507 patients with confirmed NF1, aged 18 years (y) and above (mean age 39.2y, range 18-88y; 57\% women). Five NF1 individuals were found to have MS, yielding an estimated population proportion of 3.3 per $1000(0.0033,95 \%$ Confidence Interval 0.0014-0.0077). The median age at diagnosis was 45 y (range 28-49 y). Three patients had relapsing-remitting MS and two patients had secondary progressive MS. Patients with NF1 were found to be twice more likely to develop MS than the general population in France (odds ratio 2.2), however this result was not statistically significant (95\% Confidence Interval 0.91-5.29). Our results show that patients with NF1 might have a slight increased tendency to develop MS; however, due to the small sample size of our study, the results may not be sufficiently powered to detect this rare association. Large-scale epidemiological studies based on nationwide datasets are needed to confirm our findings. These findings further emphasize the need for a focused follow-up of patients with NF1, as early detection and management of MS can prevent further neurological disability.
\end{abstract}

Keywords: Neurofibromatosis 1, Multiple sclerosis, Autoimmune disease, Genodermatosis

\section{Dear Editor,}

Neurofibromatosis 1 (NF1) is one of the most common autosomal dominant genetic disorders with a birth incidence as high as 1:2000 [1,2]. It is caused by mutations in the NF1 gene on chromosome 17 which encodes neurofibromin, a tumor suppressor protein [3, 4]. Neurofibromin regulates neuronal differentiation via its GTPase-activating protein function toward Ras [5]. By affecting multiple systems - including the cutaneous, neurologic, and orthopedic systems - NF1 leads to significant morbidity or mortality [2]. While NF1

\footnotetext{
* Correspondence: pierre.wolkenstein@aphp.fr

${ }^{1}$ Faculty of Medicine, Universite Paris-Est Creteil , Créteil, France

${ }^{2}$ Department of Dermatology, Hopital Henri Mondor, Assistance Publique-Hôpital Paris (AP-HP), Créteil, France

Full list of author information is available at the end of the article
}

individuals are predisposed to develop both benign and malignant nervous system tumors, various non-tumoral neurological conditions including learning disabilities [6] and attention deficit disorders [7] have also been reported to occur more frequently in NF1. Furthermore, NF1 has been linked to other chronic neurological conditions [8], such as epilepsy [9], sleep disorders [10], headaches [11], Parkinson's disease [12], and multiple sclerosis [12].

Multiple sclerosis (MS) is the most common immunemediated inflammatory demyelinating disease of the central nervous system (CNS) [13]. MS onset and course may depend on immunological, genetic and environmental factors [13]. Several case reports and small patient series have suggested an association between MS

(c) The Author(s). 2020 Open Access This article is licensed under a Creative Commons Attribution 4.0 International License, which permits use, sharing, adaptation, distribution and reproduction in any medium or format, as long as you give appropriate credit to the original author(s) and the source, provide a link to the Creative Commons licence, and indicate if changes were made. The images or other third party material in this article are included in the article's Creative Commons licence, unless indicated otherwise in a credit line to the material. If material is not included in the article's Creative Commons licence and your intended use is not permitted by statutory regulation or exceeds the permitted use, you will need to obtain permission directly from the copyright holder. To view a copy of this licence, visit http://creativecommons.org/licenses/by/4.0/ The Creative Commons Public Domain Dedication waiver (http://creativecommons.org/publicdomain/zero/1.0/) applies to the data made available in this article, unless otherwise stated in a credit line to the data. 
and NF1 [14-18]; however, these are limited by the lack of a non-NF1 comparison group. The number of epidemiologic studies on MS in patients with NF1 is very limited. Only one large case-control study using administrative claims data on 8579 NF1 individuals was performed and found a two-fold increased odds of MSrelated health insurance claims in people with NF1 [12]. The aim of this study was to determine the estimated population proportion of multiple sclerosis in NF1 patients followed in our Referral Centre for Neurofibromatosis.

We used the Informatics for Integrated Biology and the Bedside (i2b2) platform to extract information from the hospital's electronic health records (EHR). We performed a keyword search on clinical notes generated between Jan/01/2014 and Aug/02/2019 for patients aged 18 years $(y)$ or older. Patients with NF1 were identified using the keyword "Neurofibromatosis". The visit notes were then read thoroughly, and only patients with a confirmed NF1 diagnosis according to the National Institutes of Health criteria were included [19]. To identify NF1 patients with multiple sclerosis, the keywords "Multiple sclerosis" were entered using the Query Tool and an "and" relationship with Neurofibromatosis. Visit notes were then read to determine the NF1 phenotype, the age at diagnosis of MS, the MS subtype, the disease status at last follow-up visit, and the presence of another malignancy in the medical history. The NF1 phenotype was defined as a high-risk phenotype if the individual presented at least 10 subcutaneous neurofibromas and/ or at least one internal neurofibroma [20,21]. France is considered a country of medium-to-high MS prevalence and incidence. Prevalence of MS for the general population (1.5 per 1000) in France was obtained from an administrative data study from the main French health insurance system published in 2017 [22]. The study received institutional board review approval.

We found a total of 2215 patients with the term "Neurofibromatosis" written in their clinical notes. After reading each visit note thoroughly, a total of 1507 patients with confirmed NF1 aged 18y and above were identified (mean age 39.2y, range 18-88y; $57 \%$ women). Five NF1 individuals were found to have MS, yielding an estimated population proportion of 3.3 per $1000(0.0033,95 \%$ Confidence Interval 0.0014-0.0077). The median age at diagnosis was $45 \mathrm{y}$ ranging from 28 to $49 \mathrm{y}$ (average age $43 \mathrm{y}$ ). Three patients had relapsing-remitting MS and two patients had secondary progressive MS. None of the patients had a high-risk phenotype. Patients with NF1 were found to be twice more likely to develop MS than the general population in France (odds ratio 2.2), however this result was not statistically significant (95\% Confidence Interval 0.91-5.29).
Several case reports and case series have already indicated the potential association between NF1 and MS. [14-17] One large case-control study based on administrative claims data found a two-fold increased prevalence of MS in NF1 individuals; however, MS remains a rare complication of NF1 as it affects less than 1\% of NF1 individuals ( $0.3 \%$ in our study).

A small body of evidence suggests that this association might have a molecular explanation. The NF1 gene is located on chromosome 17q, contains 60 exons and spans $350 \mathrm{~kb}$ of genomic DNA. This NF1 gene is highly expressed in the myelin-forming oligodendrocytes which are the primary targets of the inflammatory and immune attacks in MS [23]. NF1 gene inactivation in both mice [24] and zebrafish [25] results in increased oligodendrocyte precursor cells; and NF1 loss in in NF1 geneticallyengineered mouse models results in nitric oxidemediated blood-brain barrier defects [26]. Furthermore, the gene for oligodendrocyte myelin glycoprotein $O M G$ is embedded within intron 27b of the NF1 gene. OMG is a membrane glycoprotein that appears in the human central nervous system at the time of myelination [27]. This raises the possibility that impaired OMG function could affect myelination, predisposing some NF1 individuals to MS. [18, 28] However, one study examined the $O M G$ genes of four unrelated patients with NF1 and primary progressive MS and found that only two patients had alterations in the $O M G$ gene. It was concluded that $O M G$ mutations are neither necessary nor sufficient for primary progressive MS [18]. Moreover, one study found that a mutation in the OMG gene occurred in identical proportions in MS patients and healthy controls; making the OMG gene unlikely to be involved in the genetic susceptibility to MS [28].

Another suggested hypothesis relies in the role of the neurofibromin protein as a suppressor of cellular proliferation [29]. In NF1 patients, the absence of neurofibromin activity results in cell over-proliferation and tumor formation. Loss of NF1 in the Schwann cell lineage generates tumors composed of axonal processes, Schwann cells, fibroblasts, perineurial cells, and mast cells [30]. Hypothetically, if it also has a suppressor effect on the cells of the immune system, a loss of NF1 activity might result in over-activity of the immune system in some susceptible patients [31]. Furthermore, NF1 loss in NF1 genetically-engineered mouse models was also found to cause an altered myelin structure [26]. So, it might be possible that in patients with NF1, exposure of the immune system to an altered myelin peripherally might activate an autoimmune response to the myelin expressed in the CNS. Further mechanistic analyses are needed to elucidate the relationship between NF1 and MS pathogenesis. 
Our study further confirms that the range of MS associated with NF1 includes different forms of the disease. Indeed, earlier reports on the association of NF1 and MS described patients with primary progressive forms of MS [15, 18]; but afterwards, other forms such as relapsing-remitting and secondary progressive MS associated with NF1 have been reported $[14,16]$. Accordingly, three of our patients had relapsing-remitting MS and one patient had secondary progressive MS.

An important strength of our study is that all patients had a definitive diagnosis of NF1. An important limitation is the small sample size, which led to results not sufficiently powered to detect such a rare association. Another limitation is that it is a retrospective study based on the EHR of our Referral Center for Neurofibromatosis; this hospital-based recruitment may have led to a selection bias, as patients with MS and/or more severe forms of NF1 are more prone to seek medical care in a referral center and, therefore, may lead to an overestimation of the prevalence of MS. However, our findings are consistent with previous reports.

To conclude, our results show that patients with NF1 might have an increased tendency to develop MS. These findings further emphasize the need for a focused follow-up of patients with NF1. Early detection of MS in NF1 individuals is crucial as early management could prevent further neurological disability. Large-scale epidemiological studies based on nationwide data sets are needed to confirm our findings.

\section{Abbreviations}

NF1: Neurofibromatosis 1; MS: Multiple sclerosis; i2b2: Integrated Biology and the Bedside; CNS: Central nervous system; EHR: Electronic health records

\section{Acknowledgements}

We thank Pr. Emilie Sbidian for her critical reading of the manuscript.

\section{Authors' contributions}

Christina Bergqvist wrote the initial draft of the article, to which all the authors contributed. Pierre Wolkenstein supervised the work and revised the manuscript for critical revision for important intellectual content. All authors have given final approval for the final version to be published.

\section{Funding}

None.

\section{Availability of data and materials}

Data sharing not applicable to this article as no datasets were generated or analyzed during the current study.

\section{Ethics approval and consent to participate}

Approved by the national institute concerning health data (INDS) and conducted according to local standards and laws (MR003 standard and Law Informatique et liberté number 78-1, specifying that retrospective data studies are not considered by French law as involving human subjects).

\section{Consent for publication}

Not applicable.

\section{Competing interests}

The authors declare that they have no competing interests.

\section{Author details}

${ }^{1}$ Faculty of Medicine, Universite Paris-Est Creteil , Créteil, France. ${ }^{2}$ Department of Dermatology, Hopital Henri Mondor, Assistance Publique-Hôpital Paris (AP-HP), Créteil, France. ${ }^{3}$ Department of Medical Informatics, Hôpital Henri-Mondor, Assistance Publique-Hôpitaux Paris (AP-HP), Créteil, France. ${ }^{4}$ INSERM, Centre d'Investigation Clinique 006, Hôpital Henri-Mondor, Assistance Publique-Hôpitaux Paris (AP-HP), Referral Center of Neurofibromatosis, Créteil, France.

Received: 26 April 2020 Accepted: 7 July 2020

Published online: 14 July 2020

\section{References}

1. Uusitalo E, Leppavirta J, Koffert A, et al. Incidence and mortality of neurofibromatosis: a total population study in Finland. J Invest Dermatol. 2015;135(3):904-6.

2. Gutmann DH, Ferner RE, Listernick RH, Korf BR, Wolters PL, Johnson KJ. Neurofibromatosis type 1. Nat Rev Dis Primers. 2017;3:17004.

3. Xu GF, O'Connell P, Viskochil D, et al. The neurofibromatosis type 1 gene encodes a protein related to GAP. Cell. 1990;62(3):599-608.

4. Wallace MR, Marchuk DA, Andersen LB, et al. Type 1 neurofibromatosis gene: identification of a large transcript disrupted in three NF1 patients. Science. 1990;249(4965):181-6.

5. Yunoue $\mathrm{S}$, Tokuo H, Fukunaga $\mathrm{K}$, et al. Neurofibromatosis type I tumor suppressor neurofibromin regulates neuronal differentiation via its GTPaseactivating protein function toward Ras. J Biol Chem. 2003;278(29):26958-69.

6. Hyman SL, Arthur Shores E, North KN. Learning disabilities in children with neurofibromatosis type 1: subtypes, cognitive profile, and attention-deficithyperactivity disorder. Dev Med Child Neurol. 2006;48(12):973-7.

7. Lidzba K, Granstrom S, Lindenau J, Mautner VF. The adverse influence of attention-deficit disorder with or without hyperactivity on cognition in neurofibromatosis type 1. Dev Med Child Neurol. 2012;54(10):892-7.

8. Creange A, Zeller J, Rostaing-Rigattieri S, et al. Neurological complications of neurofibromatosis type 1 in adulthood. Brain. 1999;122(Pt 3):473-81.

9. Ostendorf AP, Gutmann DH, Weisenberg JL. Epilepsy in individuals with neurofibromatosis type 1. Epilepsia. 2013;54(10):1810-4.

10. Leschziner GD, Golding JF, Ferner RE. Sleep disturbance as part of the neurofibromatosis type 1 phenotype in adults. Am J Med Genet A. 2013; 161A(6):1319-22.

11. DiMario FJ Jr, Langshur S. Headaches in patients with neurofibromatosis-1. J Child Neurol. 2000;15(4):235-8.

12. Madubata CC, Olsen MA, Stwalley DL, Gutmann DH, Johnson KJ. Neurofibromatosis type 1 and chronic neurological conditions in the United States: an administrative claims analysis. Genet Med. 2015;17(1):36-42.

13. Dobson R, Giovannoni G. Multiple sclerosis - a review. Eur J Neurol. 2019; 26(1):27-40.

14. Etemadifar M, Fatehi F, Sahraian MA, et al. Multiple sclerosis and neurofibromatosis type 1: report of seven patients from Iran. Mult Scler. 2009;15(9):1126-30.

15. Ferner RE, Hughes RA, Johnson MR. Neurofibromatosis 1 and multiple sclerosis. J Neurol Neurosurg Psychiatry. 1995;58(5):582-5.

16. Perini $P$, Gallo $P$. The range of multiple sclerosis associated with neurofibromatosis type 1. J Neurol Neurosurg Psychiatry. 2001;71(5):679-81.

17. Pipatpajong H, Phanthumchinda K. Neurofibromatosis type I associated multiple sclerosis. J Med Assoc Thail. 2011;94(4):505-10.

18. Johnson MR, Ferner RE, Bobrow M, Hughes RA. Detailed analysis of the oligodendrocyte myelin glycoprotein gene in four patients with neurofibromatosis 1 and primary progressive multiple sclerosis. J Neurol Neurosurg Psychiatry. 2000;68(5):643-6.

19. Neurofibromatosis. Conference statement. National Institutes of Health consensus development conference. Arch Neurol. 1988;45(5):575-8.

20. Sbidian E, Bastuji-Garin S, Valeyrie-Allanore L, et al. At-risk phenotype of Neurofibromatose-1 patients: a multicentre case-control study. Orphanet J Rare Dis. 2011;6:51.

21. Bergqvist C, Servy A, Valeyrie-Allanore L, et al. Neurofibromatosis 1 French national guidelines based on an extensive literature review since 1966. Orphanet J Rare Dis. 2020;15:37. https://doi.org/10.1186/s13023-020-1310-3.

22. Foulon S, Maura G, Dalichampt M, et al. Prevalence and mortality of patients with multiple sclerosis in France in 2012: a study based on French health insurance data. J Neurol. 2017;264(6):1185-92. 
23. Daston MM, Scrable H, Nordlund M, Sturbaum AK, Nissen LM, Ratner N. The protein product of the neurofibromatosis type 1 gene is expressed at highest abundance in neurons, Schwann cells, and oligodendrocytes. Neuron. 1992;8(3):415-28.

24. Bennett MR, Rizvi TA, Karyala S, McKinnon RD, Ratner N. Aberrant growth and differentiation of oligodendrocyte progenitors in neurofibromatosis type 1 mutants. J Neurosci. 2003;23(18):7207-17.

25. Lee JS, Padmanabhan A, Shin J, et al. Oligodendrocyte progenitor cell numbers and migration are regulated by the zebrafish orthologs of the NF1 tumor suppressor gene. Hum Mol Genet. 2010;19(23):4643-53.

26. Mayes DA, Rizvi TA, Titus-Mitchell $H$, et al. Nf1 loss and Ras hyperactivation in oligodendrocytes induce NOS-driven defects in myelin and vasculature. Cell Rep. 2013;4(6):1197-212.

27. Vourc'h P, Andres C. Oligodendrocyte myelin glycoprotein (OMgp): evolution, structure and function. Brain Res Brain Res Rev. 2004;45(2):115-24.

28. Hinks LJ, Price SE, Mason CR, Thompson RJ. Single strand conformation analysis of two genes contained within the first intron of the neurofibromatosis type I gene in patients with multiple sclerosis. Neuropathol Appl Neurobiol. 1995;21(3):201-7.

29. Ratner N, Miller SJ. A RASopathy gene commonly mutated in cancer: the neurofibromatosis type 1 tumour suppressor. Nat Rev Cancer. 2015;15(5): 290-301.

30. Zhu Y, Ghosh P, Charnay P, Burns DK, Parada LF. Neurofibromas in NF1: Schwann cell origin and role of tumor environment. Science. 2002; 296(5569):920-2.

31. Nanda A. Autoimmune diseases associated with neurofibromatosis type 1. Pediatr Dermatol. 2008;25(3):392-3.

\section{Publisher's Note}

Springer Nature remains neutral with regard to jurisdictional claims in published maps and institutional affiliations.

Ready to submit your research? Choose BMC and benefit from:

- fast, convenient online submission

- thorough peer review by experienced researchers in your field

- rapid publication on acceptance

- support for research data, including large and complex data types

- gold Open Access which fosters wider collaboration and increased citations

- maximum visibility for your research: over $100 \mathrm{M}$ website views per year

At $\mathrm{BMC}$, research is always in progress.

Learn more biomedcentral.com/submissions 